\title{
Analisis Rasio Keuangan Untuk Menilai Kinerja Keuangan PT. Indocement Tunggal Prakarsa Tbk. Periode Tahun 2014-2018
}

\author{
Baiq Reinelda Tri Yunarni ${ }^{1}$, Sudarta, Johanandha Fandhy Ramadhan \\ Program Studi Administrasi Niaga \\ Fakultas Ilmu Sosial dan Politik \\ Universitas Muhammadiyah Mataram
}

\begin{abstract}
The purpose of this study is to assess the financial performance of PT Indocement Tunggal Prakarsa Tbk in the period 2014 to 2018. The success of a company in achieving its goals and meeting the needs of the community is very dependent on company performance. One way to measure or evaluate performance is to analyze financial statements. This study uses a descriptive research method with a quantituve approach that is analysus based on data calculations. The data used in this study are secondary data in the form of financial statements for the period 2014 to 2018 , using the calculation of liquidity ratios, solvency, activity, and profitability. The result of this study indicate that PT Indocement Tunggal Prakarsa Tbk is in a liquid state when viewed from the liquidity ratio because the current ratio and quick ratio are above the industry standard. Judging from the solvency ratio, the financial performance of PT Indocement Tunggal Prakarsa Tbk can be said to be solvable because in terms of the debt to equity ratio, and the debt to asset ratio is below the industry standard. But the financial performance of PT Indocement Tunggal Prakarsa Tbk when viewed from the activity ratio (receivable turnover ratio, inventory turnover ratio, working capital turnover ratio, fixed assets turnover ratio, and total asset turnover ratio) and profitability ratio (net profit margin, return on investment, and return on equity) is not optimal because the company's profit continue to fall and ineffectiveness of the company in utilizing its assets
\end{abstract}

\section{Keywords: Financial Statements, Financial Ratio}

\section{PENDAHULUAN}

Pada dasarnya perusahaan memiliki tujuan untuk dapat memaksimalkan laba dan mengurangi kerugian yang dapat mengancam keberlangsungan hidup perusahaan tersebut. Keberlangsungan hidup sebuah perusahaan dapat dilihat diantaranya dari kondisi keuangan perusahaan. Informasi mengenai kondisi keuangan perusahaan dapat diketahui dari laporan keuangan yang disusun di setiap akhir periode.

Laporan keuangan adalah hasil dari proses akuntansi yang dapat digunakan sebagai alat untuk mengkomunikasikan data keuangan atau aktivitas perusahaan kepada pihak-pihak yang berkepentingan. Menurut Hery (dalam Erica, 2016) "pihak-pihak yang berkepentingan tersebut dapat berasal dari pihak internal perusahaan seperti manajemen perusahaan dan karyawan, ataupun dari pihak eksternal seperti pemegang saham, kreditor, pemerintah, dan masyarakat."
Manajemen perusahaan menggunakan laporan keuangan sebagai dasar pertimbangan dalam proses pengambilan keputusan. Manajemen perlu memahami kondisi keuangan perusahaan sebelum mengambil keputusan yang tepat, salah satunya dengan cara menilai kinerja keuangan melalui analisis keuangan perusahaan.

Hasil dari analisis laporan keuangan yang dilakukan oleh pihak manajemen perusahaan dapat memberikan beberapa informasi tentang kelemahan dan kekuatan yang dimiliki perusahaan dengan melihat hasil perbandingan rasio keuangan, seperti menghitung rasio likuiditas (liquidity ratio), rasio solvabilitas (laverage ratio), rasio aktivitas (activity ratio), dan rasio profitabilitas (profitability ratio).

Rasio likuiditas merupakan suatu indikator yang menunjukkan sejauh mana kemampuan perusahaan dalam memenuhi kewajiban jangka pendek pada saat jatuh tempo dengan menggunakan aset lancar yang tersedia. Likuiditas tidak hanya berkenaan dengan 
keadaan keseluruhan keuangan perusahaan, tetapi juga berkaitan dengan kemampuan untuk mengubah aset lancar menjadi uang kas.

Rasio solvabilitas menunjukkan sejauh mana kemampuan perusahaan untuk dapat memenuhi kewajiban dengan jaminan aset yang dimilikinya. Rasio aktivitas untuk mengukur efektivitas suatu perusahaan dalam menggunakan aktiva yang dimilikinya, sedangkan rasio profitabilitas menunjukkan sejauh mana kemampuan perusahaan dalam menghasilkan laba dengan modal yang dimilikinya.

Dengan mengetahui tingkat likuiditas, solvabilitas, aktivitas, dan profitabilitas suatu perusahaan, akan diketahui pula keadaan perusahaan yang sesungguhnya, sehingga dapat diukur tingkat kinerja keuangan dalam perusahaan. Kinerja perusahaan adalah prestasi yang dicapai perusahaan dalam periode tertentu sebagai hasil dari proses kerja pada periode tersebut. Menilai kinerja keuangan perusahaan, diperlukan suatu informasi yang relevan berkaitan dengan aktivitas perusahaan yang dapat menunjukkan bagaimana kinerja perusahaan tersebut, yaitu dengan analisis laporan keuangan.

Setiap perusahaan atau sektor industri memerlukan analisis laporan keuangan untuk mengetahui kinerja keuangan perusahaannya, termasuk juga sektor industri semen. Indonesia sebagai negara berkembang, terus melakukan upaya pembangunan yang merata guna menghilangkan kesenjangan yang ada di tiap daerah. Pembangunan tersebut terjadi di hampir setiap sektor, termasuk sektor infrastruktur yang sangat memerlukan bahan baku semen.

Pemerintah Indonesia melalui Master Plan Percepatan dan Perluasan Pembangunan Ekonomi Indonesia (MP3EI) mengalokasikan sejumlah dana APBN yang dari tahun ke tahun mengalami peningkatan, guna menyukseskan pembangunan infrakstruktur tersebut. Untuk tahun 2018, anggaran infrastruktur mencapai lebih dari 400 triliun rupiah. Anggaran tersebut naik 5,2\% jika dibandingkan dengan anggaran tahun 2017.

Tentunya dengan kenaikan anggaran tersebut akan berimbas pula terhadap permintaan semen nasional yang tentu akan meningkat. Hal itu terbukti, Menurut Asosiasi Semen Indonesia (ASI), penjualan semen pada tahun 2018 mencapai 75,2 juta ton atau meningkat $8,6 \%$ dibanding tahun sebelumnya. Sebanyak 69,51 juta ton merupakan penjualan di pasar domestik dan 5,7 juta ton dari pasar ekspor.

Kenaikan sebanyak 3,16 ton dibandingakan dengan tahun lalu didominasi peningkatan permintaan di Jawa dan Sumatera yaitu sekitar $74 \%$, sisanya $26 \%$ adalah akumulasi dari Sulawesi, Kalimantan, Nusa Tenggara, dan Wilayah Indonesia Timur. Realisasi konsumsi tahun 2018 adalah 50,75 juta ton dalam bentuk semen bag atau $73 \%$ dan semen curah sebesar 18,76 juta ton atau $27 \%$.

PT Indocement Tunggal Prakarsa Tbk (selanjutnya disebut "Perseroan" atau "Indocement") yang dikenal dengan merk kenamaannya Semen Tiga Roda dan produk barunya Semen Rajawali merupakan salah satu pemain besar dalam industri semen di Indonesia. Perseroan mengawali langkahnya pada tahun 1975 dengan didirikannya sebuah pabrik semen di wilayah Citeureup, Jawa Barat oleh PT Distinct Indonesia Cement Enterprise (DICE) dengan kapasitas produksi awal 500.000 ton.

Guna mengantisipasi pertumbuhan pasar yang semakin kuat, Indocement terus berupaya menambah kapasitas produksinya dengan cara menambah jumlah pabrik dan melakukan merger dengan pabrik semen yang lain. Sehingga sampai dengan tahun 2018, Perseroan telah memiliki 13 pabrik dengan total kapasitas produksi sebesar 24,9 juta ton semen.

Peningkatan pangsa pasar juga membuat penjualan semen domestik Indocement mengalami peningkatan sebesar 5,7\% dibandingkan tahun 2017. Pertumbuhan ini berada di atas rata-rata pertumbuhan industri semen nasional yang hanya $4,8 \%$. Namun berbeda halnya dengan penjualan semen untuk ekspor yang turun sebesar 32\%, dari 69 ribu ton pada 2017 menjadi 47 ribu ton pada 2018.

Namun, ditengah kenaikan produksi dan realisasi produksi yang meningkat dibandingkan tahun sebelumnya, laba perusahaan justru mengalami penurunan dibandingkan tahun sebelumnya. Laba 
terendah adalah pada tahun 2018 jika dibandingkan dengan tahun sebelumnya. Meskipun perusahaan tetap dalam kondisi laba, tetapi penurunan laba secara terus menerus akan berpengaruh pula terhadap operasional perusahaan.

Selain itu, penurunan laba usaha tentu akan berpengaruh terhadap investor yang menanamkan saham di sebuah perusahaan. Sebagai perusahaan yang terdaftar dalam Bursa Efek Indonesia (BEI), PT Indocement Tunggal Prakarsa Tbk tentunya akan melaporkan kondisi yang ada kepada para pemegang saham, dengan kondisi dimana laba usaha yang turun, tentu akan berpengaruh kepada harga saham perusahaan.

Kinerja operasional perusahaan yang sedang meningkat ternyata tidak selalu diikuti dengan peningkatan laba usaha. Meskipun tingkat produksi dan penjualan semen pada tahun 2018 meningkat dibandingkan tahun sebelumnya, laba usaha justru menurun dibandingakan tahun sebelumnya. Beberapa faktor diyakini mempengaruhi hal tersebut.

\section{Rumusan Masalah}

Berdasarkan latar belakang yang telah diuraikan sebelumnya, maka rumusan masalah dalam penelitian ini adalah bagaimanakah kinerja keuangan perusahaan PT Indocement Tunggal Prakarsa Tbk selama periode tahun 2014 sampai 2018 ?

\section{TINJAUAN PUSTAKA}

\section{Laporan Keuangan}

Ikatan Akuntansi Indonesia (dalam Harahap, 2018) berpendapat bahwa laporan keuangan merupakan bagian dari proses pelaporan keuangan. Sebuah laporan keuangan yang lengkap terdiri dari neraca, laporan laba rugi, laporan perubahan posisi keuangan, catatan, dan laporan lain serta materi penjelasan.

Menurut Hanafi (dalam Fithriyah, 2018) "laporan keuangan perusahaan merupakan salah satu sumber informasi yang penting di samping informasi lain seperti informasi industri, kondisi perekonomian, pangsa pasar perusahaan, kualitas manajemen dan lainnya".
Sedangkan Munawir (dalam Ridha, 2017) berpendapat bahwa laporan keuangan merupakan hasil dari proses akuntansi. Tiga laporan utama yang terdapat pada laporan keuangan adalah (1) balance sheet atau statement of financial position atau neraca (2) laporan laba rugi (3) laporan arus kas dan sebagai tambahan disusun pula laporan perubahan modal

Berbeda halnya menurut Kasmir (2008:7), menurutnya laporan keuangan adalah laporan yang menunjukkan kondisi keuangan perusahaan pada saat ini atau dalam suatu periode tertentu. Dengan demikian, secara umum laporan keuangan merupakan catatan informasi keuangan suatu perusahaan pada suatu periode akuntansi yang dapat digunakan untuk menggambarkan kinerja perusahaan tersebut.

\section{Tujuan Laporan Keuangan}

Setiap laporan keuangan yang dibuat pasti memiliki tujuan tertentu bagi seluruh pihak yang berkepentingan. Menurut Pernyataan Standar Akuntansi Keuangan (PSAK) No. 1 (dalam Fithriyah, 2018), tujuan laporan keuangan memberikan informasi mengenai posisi keuangan, kinerja keuangan, dan arus kas entitas yang bermanfaat bagi sebagian besar kalangan pengguna laporan dalam pembuatan keputusan ekonomi.

Laporan keuangan yang disusun untuk tujuan ini memenuhi kebutuhan bersama sebagian besar pengguna. Namun demikian, laporan keuangan tidak menyediakan semua informasi yang mungkin dibutuhkan dalam pengambilan keputusan ekonomi karena secara umum menggambarkan pengaruh keuangan dari kejadian di masa lalu dan tidak diwajibkan untuk menyediakan informasi non keuangan. Laporan keuangan harus menyajikan informasi-informasi yang meliputi: Aset, Liabilitas, Ekuitas, Pendapatan dan beban termasuk keuntungan dan kerugian, Kontribusi dari dan distribusi kepada pemilik dalam kapasitasnya sebagai pemilik, serta Arus kas.

Informasi yang lengkap tersebut dapat membantu pengguna laporan dalam memprediksi arus kas masa depan dan khususnya dalam waktu dan kepastian diperolehnya kas dan setara kas. 


\section{Pihak Yang Memerlukan Laporan Keuangan}

Laporan keuangan disusun berdasarkan berbagai tujuan. Tujuan utamanya adalah untuk kepentingan pemilik dan manajemen perusahaan dan memberikan informasi kepada berbagai pihak yang berkepentingan dengan perusahaan. Artinya pembuatan dan penyusunan laporan keuangan ditujukan untuk memenuhi kepentingan berbagai pihak, baik itu pihak internal maupun pihak eksternal.

Menurut Kasmir (2008:18), pihak-pihak yang berkepentingan terhadap laporan keuangan adalah:

1. Pemilik

Laporan keuangan digunakan untuk melihat kondisi dan perkembangan perusahaan. Selain itu berfungsi juga untuk menilai kinerja manajemen atas target yang telah ditetapkan.

2. Manajemen

Laporan keuangan digunakan sebagai cermin kinerja mereka dalam suatu periode tertentu. Selain itu berfungsi pula sebagai pertimbangan dalam pengamilan keputusan.

3. Investor

Bagi investor yang akan menanamkan sahamnya di sebuah perusahaan, perlu melihat dan memperhitungkan secara matang sebelum memutuskan untuk membeli sebuah saham. Dasar pengambilan keputusan tersebut tentu saja adalah laporan keuangan.

4. Kreditor

Kreditor merupakan penyandang dana bagi perusahaan. Prinsip kehati-hatian tentu akan sangat diberlakukan oleh penyandang dana sebelum menyalurkan dananya ke sebuah perusahaan.

5. Pemerintah (Stakeholder)

Pemerintah juga memiliki peran penting atas laporan keuangan yang dibuat oleh perusahaan. Melalui Kementerian Keuangan, pemerintah akan memungut pajak sesuai dengan laporan keuangan yang telah disajikan oleh perusahaan.

\section{Analisis Laporan Keuangan}

Apabila sebuah laporan keuangan telah disusun sedemikian rupa mengikuti kaidah akuntansi dan penilaian yang benar, maka akan terlihat kondisi keuangan perusahaan yang sesungguhnya. Kondisi keuangan yang dimaksud adalah diketahuinya berapa jumlah harta, utang, serta ekuitas dalam neraca yang dimiliki. Kemudian akan diketahui pula pendapatan yang diterima dan jumlah biaya yang dikeluarkan selama periode tertentu. Yang akhirnya dapat diketahui pula hasil usaha perusahaan pada periode tertentu dari laporan laba rugi yang telah disajikan.

Analisis laporan keuangan perlu dilakukan secara cermat dengan menggunakan metode dan teknik analisis yang tepat sehingga hasil yang diharapkan benar-benar tepat. Kesalahan dalam memasukkan angka atau rumus akan berakibat pada tidak akuratnya hasil yang hendak dicapai. Kemudian hasil perhitungan tersebut dianalisis dan diinterpretasikan sehingga diketahui posisi keuangan yang sesungguhnya. Kesemuanya ini harus dilakukan secara teliti, mendalam, dan jujur.

\section{Analisis Rasio Keuangan}

Pada akhir periode, pihak manajemen khususnya bagian keuangan selalu menyiapkan dan menyusun laporan keuangan untuk diserahkan kepada pimpinan perusahaan. Laporan tersebut berisi angka-angka pada suatu akun yang menunjukkan kondisi keuangan perusahaan yang sebenarnya. Dengan membandingkan angka-angka itu, maka akan terlihat kinerja perusahaan secara terperinci, sehingga pimpinan dapat menilai apakah kinerja perusahaan mengalami kenaikan atau penurunan.

Namun selain laporan keuangan, ada hal lain yang penting dan perlu untuk disajikan dalam penyampaian laporan keuangan yaitu mengenai analisis laporan keuangan (financial statement analysis). Menurut James C Van Horne (dalam Kasmir, 2008), rasio keuangan (financial ratio) merupakan indeks yang menghubungkan dua angka akuntansi dan diperoleh dengan membagi satu angka dengan angka lainnya. Rasio keuangan digunakan untuk mengevaluasi kondisi keuangan dan kinerja perusahaan. Dari hasil rasio keuangan ini akan terlihat kondisi kesehatan perusahaan yang bersangkutan. 


\section{Rasio Likuiditas}

Rasio likuiditas merupakan rasio yang menggambarkan kemampuan perusahaan memenuhi kewajiban (utang) jangka pendek. Rasio likuiditas berfungsi untuk menunjukkan atau mengukur kemampuan perusahaan dalam memenuhi kewajibannya yang sudah jatuh tempo, baik kewajiban kepada pihak luar perusahaan maupun di dalam perusahaan (Kasmir, 2008:129). Adapun jenis-jenis rasio likuiditas antara lain:

\section{Rasio Lancar (Current Ratio)}

Rasio Lancar (Current Ratio) merupakan rasio untuk mengukur kemampuan perusahaan dalam membayar kewajiban jangka pendek atau utang yang segera jatuh tempo pada saat ditagih secara keseluruhan. Dengan kata lain, seberapa banyak aktiva lancar yang tersedia untuk menutupi kewajiban jangka pendek yang segera jatuh tempo. Rasio lancar dapat pula dikatakan sebagai bentuk untuk mengukur tingkat keamanan (margin of safety) suatu perusahaan (Kasmir, 2008:134-135).

Rumus untuk mencari rasio lancar adalah sebagai berikut:

Current Ratio $=\frac{\text { Current Assets }}{\text { Current Liabilities }}$

\section{Rasio Cepat (Quick Ratio)}

Rasio Cepat (Quick Ratio) merupakan rasio yang menunjukkan kemampuan perusahaan dalam memenuhi atau membayar kewajiban atau utang lancar (jangka pendek) dengan aktiva lancar tanpa memperhitungkan nilai sediaan (inventory). (Kasmir, 2008:137)

Rumus untuk mencari rasio cepat adalah sebagai berikut:

$$
\text { Quick Ratio }=\frac{(\text { Current Assets }- \text { Inventory })}{\text { Current Liabilities }}
$$

\section{Rasio Solvabilitas}

Rasio solvabilitas merupakan rasio yang digunakan untuk mengukur sejauh mana aktiva perusahaan dibiayai dengan utang. Artinya berapa besar beban utang yang ditanggung perusahaan dibandingkan dengan aktivanya. Dalam arti luas dikatakan bahwa rasio solvabilitas digunakan untuk mengukur kemampuan perusahaan untuk membayar seluruh kewajiban, baik jangka pendek maupun jangka panjang apabila perusahaan dibubarkan (dilikuidasi) (Kasmir, 2015:151). Adapun jenis-jenis rasio solvabilitas antara lain:

1. Rasio Hutang terhadap Total Aktiva/Debt to Assets Ratio

Rasio hutang terhadap total aktiva/debt to Assets Ratio merupakan rasio utang yang digunakan untuk mengukur perbandingan antara total utang dengan total aktiva. Dengan kata lain, seberapa besar aktiva perusahaan dibiayai oleh utang atau seberapa besar utang perusahaan berpengaruh terhadap pengelolaan aktiva (Kasmir, 2008:156).

Rumus yang digunakan untuk mencari debt to assets ratio adalah sebagai berikut:

$$
\text { Debt Ratio }=\frac{\text { Total Debt }}{\text { Total Assets }}
$$

2. Rasio Hutang terhadap Ekuitas/Debt to Equity Ratio

Rasio hutang terhadap ekuitas/debt to equity ratio merupakan rasio yang digunakan untuk menilai utang dengan ekuitas. Rasio ini dicari dengan cara membandingkan antara seluruh utang, termasuk utang lancar dengan seluruh ekuitas. Rasio ini berfungsi untuk mengetahui setiap rupiah modal sendiri yang dijadikan untuk jaminan utang (Kasmir, 2008:158).

Rumus yang digunakan untuk mencari debt to equity ratio adalah sebagai berikut:

$$
\text { Debt to Equity Ratio }=\frac{\text { Total utang }(\text { debt })}{\text { Ekuitas }(\text { equity })}
$$

\section{Rasio Aktivitas}

Rasio aktivitas merupakan rasio yang digunakan untuk mengukur efektivitas perusahaan dalam menggunakan aktiva yang dimilikinya. Atau dapat pula dikatakan rasio ini digunakan untuk mengukur tingkat efisiensi (efektivitas) pemanfaatan sumber daya perusahaan (Kasmir, 2008:172). Adapun jenisjenis rasio aktivitas antara lain:

\section{Perputaran Piutang/Receivable Turnover} Ratio

Perputaran piutang merupakan rasio yang digunakan untuk mengukur berapa lama penagihan piutang selama satu periode 
atau beberapa kali dana yang ditanam dalam piutang ini berputar dalam satu periode (Kasmir, 2008:176).

Rumus untuk mencari perputaran piutang adalah sebagai berikut:

Receivable Turnover Ratio $=\frac{\text { Penjualan }}{\text { Rata }- \text { rata Piutang }}$

2. Perputaran Persediaan/Inventory Turnover Ratio

Perputaran persediaan merupakan kemampuan dana yang tertanam dalam sediaan berputar dalam suatu periode tertentu, atau likuiditas dari sediaan dan tendensi untuk adanya overstock (Kasmir, 2008:180).

Rumus untuk mencari perputaran sediaan adalah sebagai berikut:

$$
\text { Inventory Turnover Ratio }=\frac{\text { Penjualan }}{\text { Persediaan (inventory) }}
$$

3. Perputaran Modal Kerja/Working Capital Turnover Ratio

Perputaran modal kerja merupakan salah satu rasio untuk mengukur atau menilai keefektifan modal kerja perusahaan selama periode tertentu (Kasmir, 2008:182).

Rumus untuk mencari perputaran modal kerja adalah sebagai berikut:

$$
\text { Working Capital Turnover Ratio }=\frac{\text { Penjualan Bersih }}{\text { Modal kerja }}
$$

4. Perputaran Aktiva Tetap/Fixed Assets Turnover Ratio

Fixed assets turnover ratio merupakan rasio yang digunakan untuk mengukur berapa kali dana yang ditanamkan dalam aktiva tetap berputar dalam satu periode (Kasmir, 2008:184).

Rumus untuk mencari fixed assets turnover ratio adalah sebagai berikut:

$$
\text { Fixed Assets Turnover Ratio }=\frac{\text { Penjualan }}{\text { Total Aktiva Tetap }}
$$

5. Perputaran Total Aktiva/Total Assets Turnover Ratio

Total assets turnover ratio merupakan rasio yang digunakan untuk mengukur perputaran semua aktiva yang dimiliki perusahaan dan mengukur berapa jumlah penjualan yang diperoleh dari tiap rupiah aktiva (Kasmir, 2008:186).

Rumus untuk mencari total assets turnover ratio adalah sebagai berikut:

\section{Rasio Profitabilitas}

$$
\text { Total Assets Turnover Ratio }=\frac{\text { Penjualan }}{\text { Total Aktiva }}
$$

Rasio profitabilitas merupakan rasio untuk menilai kemampuan perusahaan dalam mencari keuntungan. Rasio ini juga memberikan ukuran tingat efektivitas manajemen suatu perusahaan (Kasmir, 2008:196). Untuk mengetahui rasio profitabilitas dapat digunakan beberapa cara, antara lain adalah sebagai berikut:

1. Rasio Profit Margin (Profit Margin on Sales)

Rasio profit margin merupakan salah satu rasio yang digunakan untuk mengukur margin laba atas penjualan (Kasmir, 2008:199). Terdapat dua rumus untuk mencari margin laba, yaitu sebagai berikut:

a. Untuk margin laba kotor

$$
=\frac{\begin{array}{c}
\text { Profit Margin } \\
\text { (Penjualan bersih }- \text { Harga pokok penjualan })
\end{array}}{\text { Sales }}
$$

b. Untuk margin laba bersih Net Profit Margin $=\frac{\text { Earning after interest and tax }(E A I T)}{\text { Sales }}$

2. Hasil Pengembalian Investasi (Return on Investment/ROI)

ROI merupakan rasio yang menunjukkan hasil (return) atas jumlah aktiva yang digunakan dalam perusahaan. ROI juga merupakan suatu ukuran tentang efektivitas manajemen dalam mengelola investasinya (Kasmir, 2008:201).

Rumus untuk mencari ROI adalah sebagai berikut:

$$
\text { Return on Investment }=\frac{\text { Earning After Interest and Tax }}{\text { Total Assets }}
$$

3. Hasil Pengembalian Ekuitas (Return on Equity/ROE)

ROE merupakan rasio untuk mengukur laba bersih sesudah pajak dengan modal sendiri. Rasio ini menunjukkan efisiensi 
penggunaan modal sendiri pada perusahaan (Kasmir, 2008:203).

$$
\begin{gathered}
\begin{array}{c}
\text { Rumus untuk mencari ROE } \\
\text { adalah sebagai berikut: }
\end{array} \\
\text { Return on Equity }=\frac{\text { Earning After Interest and Tax }}{\text { Equity }}
\end{gathered}
$$

\section{Metode Analisis Rasio Keuangan}

Ada dua cara yang dapat dilakukan di dalam membandingkan rasio keuangan perusahaan menurut Syamsuddin (dalam Fithriyah, 2018), antara lain:

\section{Cross section approach}

Adalah suatu cara mengevaluasi dengan jalan membandingkan rasio-rasio antara perusahaan yang satu dengan yang lainnya yang sejenis pada saat yang bersangkutan.

2. Time series

Adalah suatu analisis yang dilakukan dengan jalan membandingkan rasio finansial perusahaan dari satu periode ke periode lainnya. Pembandingan dilakukan apakah perusahaan mengalami kemajuan atau kemunduran.

\section{Kinerja Keuangan}

Kinerja perusahaan adalah suatu usaha formal yang dilaksanakan perusahaan untuk mengevaluasi efisien dan efektivitas dari aktivitas perusahaan yang telah dilaksanakan pada periode waktu tertentu. Menurut Sucipto (dalam Gunawan, 2012) kinerja keuangan adalah penentuan ukuran-ukuran tertentu yang dapat mengukur keberhasilan suatu organisasi atau perusahaan dalam menghasilkan laba.

Menurut Fidhayatin (dalam Nurudin, 2018) "perusahaan yang sehat nantinya akan dapat memberikan laba bagi para pemilik modal, perusahaan yang sehat juga dapat membayar hutang dengan tepat waktu". Kinerja keuangan memberikan informasi mengenai baik buruknya suatu organisasi melalui kegiatan perusahaan.

Fahmi (dalam Maith, 2013:621) menyatakan bahwa kinerja keuangan adalah suatu analisis yang dilakukan untuk melihat sejauh mana perusahaan telah melaksanakan dengan menggunakan aturan-aturan pelaksanaan keuangan secara baik dan benar. Dengan pengukuran kinerja keuangan, dapat dilihat prospek pertumbuhan dan perkembangan keuangan perusahaan. Perusahaan dikatakan berhasil apabila perusahaan telah mencapai suatu kinerja tertentu yang telah ditetapkan.

Dari pengertian diatas dapat disimpulkan bahwa kinerja keuangan merupakan cerminan keadaan perusahaan pada suatu periode tertentu. Dari kinerja keuangan perusahaan dapat pula dilihat prestasi perusahaan berdasarkan analisis kinerja keuangan perusahaan tersebut.

\section{Tahapan dalam Menganalisis Kinerja Keuangan}

Penilaian kinerja di setiap perusahaan berbeda, semua tergantung pada ruang lingkup bisnis yang dijalankannya. Setiap sektor usaha memiliki cara atau tahapan tersendiri dalam menilai kinerja perusahaan. Ada 5 tahap dalam menganalisis kinerja keuangan suatu persahaan secara umum menurut Irham (dalam Yani, 2016), yaitu:

1. Melakukan review terhadap data laporan keuangan.

Review disini dilakukan dengan tujuan agar laporan keuangan yang sudah dibuat tersebut sesuai dengan penerapan kaidahkaidah yang berlaku umum dalam dunia akuntansi, sehingga dengan demikian hasil laporan keuangan tersebut dapat dipertanggungjawabkan.

2. Melakukan perhitungan.

Penerapan metode hitungan disini adalah disesuaikan dengan kondisi dan permasalahan yang sedang dilakukan sehingga hasil dari perhitungan tersebut akan memberikan suatu kesimpulan sesuai dengan analisis yang diinginkan.

3. Melakukan perbandingan terhadap hasil hitungan yang telah diperoleh.

Dari hasil hitungan yang sudah diperoleh tersebut kemudian dilakukan perbandingan dengan hasil hitungan dari berbagai perusahaan lainnya.

4. Melakukan penafsiran terhadap berbagai permasalahan yang ditemukan.

Pada tahap ini analisis melihat kinerja keuangan perusahaan adalah setelah dilakukan ketiga tahap tersebut selanjutnya dilakukan penafsiran untuk melihat apa saja permasalahan dan kendala-kendala yang dialami oleh perusahaan tersebut. 
5. Mencari dan memberikan pemecahan masalah terhadap berbagai permasalahan yang ditemukan. Pada tahap terakhir ini setelah ditemukan berbagai permasalahan yang dihadapi maka dicarikan solusi guna memberikan input atau masukan agar apa saja yang menjadi kendala dan hambatan selama ini dapat terselesaikan.

\section{KERANGKA KONSEPTUAL DAN PENGEMBANGAN HIPOTESIS \\ Kerangka Konseptual}

Penelitian ini akan meneliti posisi keuangan dan kinerja sebuah perusahaan. Posisi keuangan perusahaan mencerminkan kemampuan pengelolaan keuangan perusahaan dalam menjalankan aktivitas perusahaan. Sedangkan kinerja keuangan perusahaan mencerminkan kemampuan pengelolaan keuangan perusahaan dalam menjalankan aktivitas perusahaan. Untuk dapat mengetahui posisi dan kinerja keuangan perusahaan diperlukan sebuah analisis laporan keuangan.

Untuk menganalisis sebuah laporan keuangan diperlukan sebuah metode analisis keuangan, salah satunya adalah analisis rasio. Pada penelitian kali ini, peneliti menggunakan analisis rasio untuk menentukan posisi keuangan perusahaan. Analisis rasio bertujuan untuk mengukur tingkat efektivitas keputusan yang telah diambil oleh perusahaan dalam menjalankan usahanya. Jenis rasio yang akan digunakan dalam penelitian ini adalah rasio likuiditas, rasio solvabilitas, rasio aktivitas, dan rasio profitabilitas. Analisis rasio likuiditas bertujuan untuk mengukur kemampuan sebuah perusahaan dalam memenuhi kewajibannya pada saat jatuh tempo. Analisis rasio likuiditas dapat dihitung dengan current ratio dan quick ratio.

Analisis rasio solvabilitas berguna untuk mengukur kemampuan perusahaan untuk membayar seluruh kewajibannya, baik jangka pendek maupun jangka panjang apabila perusahaan dibubarkan (dilikuidasi). Analisis rasio solvabilitas dapat dihitung dengan debt to assets ratio dan debt to equity ratio.

Analisis rasio aktivitas berguna untuk mengukur tingkat efektivitas sebuah perusahaan dalam menggunakan aktiva yang dimilikinya. Analisis rasio aktivitas dapat dihitung dengan perputaran piutang, perputaran persediaan, perputaran modal kerja, fixed assets turnover ratio, dan total assets turnover.

Analisis rasio profitabilitas berguna untuk mengukur kemampuan perusahaan dalam mencari keuntungan serta memberikan ukuran tingkat efektivitas manajemen suatu perusahaan. Analisis rasio profitabilitas dapat dihitung dengan net profit margin, return on investment, dan return on equity.

\section{Gambar 1}

Kerangka Berfikir Penilaian Kinerja

Keuangan

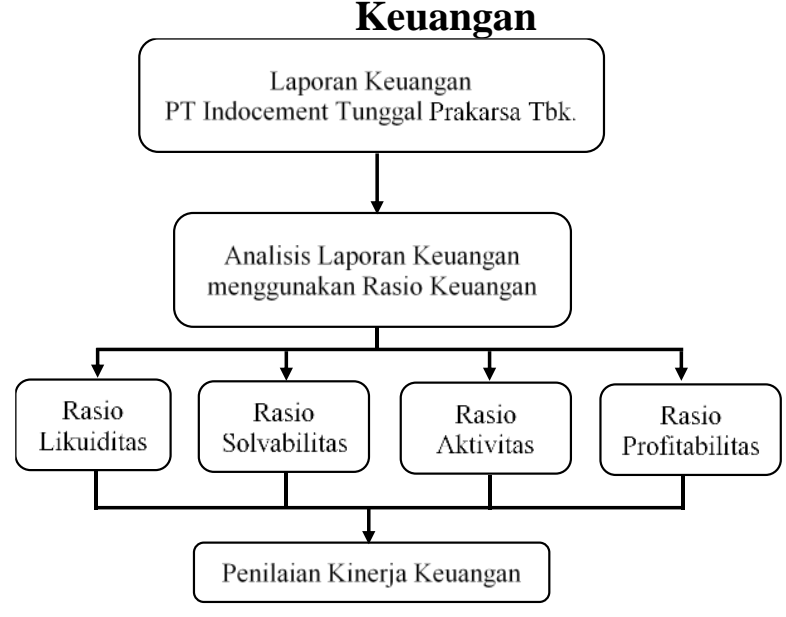

\section{METODE PENELITIAN}

Desain Penelitian

Penelitian ini merupakan penelitian deskriptif dengan pendekatan kuantitatif. Penelitian kuantitatif sendiri merupakan penelitian yang berbentuk angka. Menggunakan metode deskriptif yang bersifat kuantitatif karena penelitian ini berkaitan dengan objek penelitian yaitu pada perusahaan dengan kurun waktu tertentu dengan mengumpulkan data dan informasi yang berkaitan dengan perusahaan dan disesuaikan dengan tujuan penelitian.

\section{Objek Penelitian}

Objek penelitian ini adalah perusahaan PT Indocement Tunggal Prakarsa Tbk Periode Tahun 2014-2018

\section{Jenis dan Sumber Data}

Data yang dipergunakan dalam penelitian ini adalah data sekunder, yaitu data yang diperoleh dalam bentuk yang sudah jadi, dikumpulkan dan diolah oleh perusahaan atau pihak yang bersangkutan, meliputi laporan 
neraca, laporan laba rugi, laporan arus kas perusahaan selama periode 2014-2018.

Data sekunder yang merupakan gabungan antara data time series (data tahunan) dan cross section dengan periode data yang diambil mulai dari tahun 2014 hingga tahun 2018. Data time series adalah data yang dikumpulkan dari waktu ke waktu pada satu objek untuk menggambarkan perkembangannya. Sedangkan data cross section adalah data yang dikumpulkan pada satu waktu tertentu pada beberapa objek dengan tujuan untuk menggambarkan keadaan.

\section{Teknik Pengumpulan Data}

Teknik pengumpulan data yang digunakan adalah metode dokumentasi. Metode ini dilakukan melalui pengumpulan dan pencatatan dari data historis perusahaan semen, studi literatur, laporan penelitian, dan laporan keuangan yang diterbitkan perusahaan. Data ini diperoleh melalui website perusahaan: www.indocement.co.id.

\section{Analisis Data}

Metode analisis yang digunakan dalam penelitian ini adalah metode analisis horizontal, yaitu analisis yang dilakukan dengan membandingkan laporan keuangan dalam berbagai periode waktu sehingga dapat diketahui perkembangannya (Kasmir, 2008:69). Teknik analisis data yang digunakan adalah dengan menggunakan pendekatan metode kuantitatif, yaitu dengan menghitung rasio-rasio yang ada di perusahaan.

\section{Rasio Likuiditas}

Rasio ini mengukur kemampuan perusahaan dalam memenuhi kewajibannya yang sudah jatuh tempo, baik kewajiban kepada pihak luar perusahaan maupun di dalam perusahaan

\section{Tabel 1. Standar Industri Rasio Likuiditas}

Sumber: Kasmir (2008:143)

a. Rasio Lancar (Current Ratio)

$$
\text { Current Ratio }=\frac{\text { Current Assets }}{\text { Current Liabilities }}
$$

b. Rasio Cepat (Quick Ratio)

$$
\text { Quick Ratio }=\frac{\text { (Current Assets }- \text { Inventory) }}{\text { Current Liabilities }}
$$

\section{Rasio Solvabilitas}

Rasio ini digunakan untuk mengukur sejauh mana aktiva perusahaan dibiayai dengan utang.
Artinya berapa besar beban utang yang ditanggung perusahaan dibandingkan dengan aktivanya.

Tabel 2.Standar Industri Rasio Solvabilitas

\begin{tabular}{|r|c|c|}
\hline \multicolumn{1}{|l|}{ No } & Jenis Rasio & Standar Industri \\
\hline 1 & Current Ratio (Rasio Lancar) & 2 kali \\
\hline 2 & Quick Ratio (Rasio Cepat) & 1,5 kali \\
\hline
\end{tabular}

Sumber: Kasmir (2008:164)

a. Debt to Asset Ratio

b. Debt to Equity Ratio

Debt Ratio $=\frac{\text { Total Debt }}{\text { Total Assets }}$

Debt to Equity Ratio $=\frac{\text { Total utang }(\text { debt })}{\text { Ekuitas }(\text { equity) }}$

Rasio Aktivitas

Rasio ini digunakan untuk mengukur efektivitas perusahaan dalam menggunakan aktiva yang dimilikinya. Atau dapat pula dikatakan rasio ini digunakan untuk mengukur tingkat efisiensi (efektivitas) pemanfaatan sumber daya perusahaan.

Tabel 3. Standar Industri Rasio Aktivitas

\begin{tabular}{r|l|c}
\hline No & \multicolumn{1}{|c|}{ Jenis Rasio } & $\begin{array}{c}\text { Standar } \\
\text { Industri }\end{array}$ \\
\hline 1 & Perputaran Piutang (Receivable Turnover Ratio) & $15 \mathrm{kali}$ \\
\hline 2 & Perputaran Sediaan (Inventory Turnover Ratio) & $20 \mathrm{kali}$ \\
\hline 3 & Perputaran Modal Kerja (Working Capital Turnover Ratio) & $6 \mathrm{kali}$ \\
\hline 4 & Perputaran Aset Tetap (Fixed Assets Turnover Ratio) & $5 \mathrm{kali}$ \\
\hline 5 & Perputaran Total Aset (Total Assets Turnover Ratio) & 2 kali \\
\hline
\end{tabular}

Sumber: Kasmir (2008:187)

a. Perputaran Piutang (Receivable Turnover Ratio)

Receivable Turnover Ratio $=\frac{\text { Penjualan }}{\text { Rata }- \text { rata Piutang }}$

b. Perputaran Persediaan (Inventory Turnover Ratio)

Inventory Turnover Ratio $=\frac{\text { Penjualan }}{\text { Persediaan }}$

c. Perputaran Modal Kerja (Working Capital Turnover Ratio)

Working Capital Turnover Ratio $=\frac{\text { Penjualan Bersih }}{\text { Modal kerja }}$

d. Fixed Assets Turnover Ratio

Fixed Assets Turnover Ratio $=\frac{\text { Penjualan }}{\text { Total Aktiva Tetap }}$

e. Total Assets Turn Over

Total Assets Turnover Ratio $=\frac{\text { Penjualan }}{\text { Total Aktiva }}$

\section{Rasio Profitabilitas}

Rasio ini bertujuan untuk menilai kemampuan perusahaan dalam mencari keuntungan. Rasio ini juga memberikan ukuran tingat efektivitas manajemen suatu perusahaan. 
Tabel 4.Standar Industri Rasio Profitabilitas

\begin{tabular}{|c|l|c|}
\hline No & \multicolumn{1}{|c|}{ Jenis Rasio } & $\begin{array}{r}\text { Standar } \\
\text { Industri }\end{array}$ \\
\hline 1 & $\begin{array}{l}\text { Margin Laba Bersih (Net } \\
\text { Profit Margin) }\end{array}$ & $20 \%$ \\
\hline 2 & Return On Investment (ROI) & $30 \%$ \\
\hline 3 & Return On Equity (ROE) & $40 \%$ \\
\hline
\end{tabular}

Sumber: Kasmir (2008:208)

a. Rasio Profit Margin (Profit Margin on Sales)

Net Profit Margin $=\frac{\text { EAT }(\text { Laba Bersih })}{\text { Sales }(\text { Penjualan })}$

b. Hasil Pengembalian Investasi (Return on Investment/ROI)

Return on Investment $=\frac{\text { Earning After Interest and Tax }}{\text { Total Assets }}$

c. Hasil Pengembalian Ekuitas (Return on Equity/ROE)

Return on Equity $=\frac{\text { Earning After Interest and Tax }}{\text { Equity }}$

\section{HASIL ANALISIS}

Analisis dalam penelitian ini adalah analisis rasio keuangan yang dilakukan berdasarkan daa laporan keuangan perusahaan yang terdiri dari laporan posisi keuangan dan laporan laba rugi komprehensif selama lima tahun mulai dari tahun 2014 hingga 2018. Adapun analisis yang digunakan dalam penelitian ini adalah analisis rasio keuangan yang terdiri dari rasio likuiditas, solvabilitas, aktivitas dan profitabilitas.

\section{Analisis Rasio Likuiditas}

a. Rasio Lancar/Current Ratio (CR)

Rasio lancar/current ratio yang rendah menunjukkan likuiditas yang rendah. Sebaliknya, rasio lancar tinggi menunjukkan kelebihan aktiva lancar, tetapi mempunyai pengaruh yang tidak baik terhadap profitabilitas perusahaan (Hanafi, 2013:37).

Berikut perhitungan Rasio Lancar mulai tahun 2014 hingga 2018:

Tabel 5. Perhitungan Rasio Lancar/ Current Ratio (CR) PT Indocement Tunggal Prakarsa Tbk. (dalam jutaan rupiah)

\begin{tabular}{|c|c|c|c|}
\hline Tahun & $\begin{array}{c}\text { Aktiva } \\
\text { Lancar }\end{array}$ & $\begin{array}{c}\text { Hutang } \\
\text { Lancar }\end{array}$ & $\begin{array}{c}\text { Current Ratio } \\
(\text { CR })\end{array}$ \\
\hline 2014 & 16.086 .773 & 3.260 .559 & 4,93 \\
\hline 2015 & 13.133 .854 & 2.687 .743 & 4,89 \\
\hline 2016 & 14.424 .622 & 3.187 .742 & 4,52 \\
\hline 2017 & 12.883 .074 & 3.479 .024 & 3,70 \\
\hline 2018 & 12.315 .796 & 3.925 .649 & 3,14 \\
\hline
\end{tabular}

Sumber: Data diolah peneliti 2020.
Tabel 5 menunjukkan bahwa tahun 2014, rasio lancar yang dihasilkan sebesar 4,93, yang menunjukkan bahwa setiap $\mathrm{Rp} 1,00$ utang dijamin oleh $\mathrm{Rp} 4,93$ aktiva lancar. Pada tahun 2015, rasio lancar yang dihasilkan sebesar 4,89, yang menunjukkan bahwa setiap Rp 1,00 utang dijamin oleh Rp 4,89 aktiva lancar.

Pada tahun 2016, rasio lancar yang dihasilkan adalah 4,52 yang menunjukkan bahwa setiap $\mathrm{Rp} 1,00$ utang dijamin oleh $\mathrm{Rp}$ 4,52 aktiva lancar. Pada tahun 2017, rasio lancar yang dihasilkan adalah 3,70 yang menunjukkan bahwa setiap $\mathrm{Rp} 1,00$ utang dijamin oleh $\mathrm{Rp} 3,70$ aktiva lancar.

Dan pada tahun 2018, rasio lancar yang dihasilkan adalah sebesar 3,14 yang menunjukkan bahwa setiap Rp 1,00 utang dijamin oleh Rp 3,14 aktiva lancar. Bisa dilihat pada diagram di bawah ini tingkat pertumbuhan rasio lancar PT Indocement Tunggal Prakarsa Tbk tahun 2014-2018.

Berdasarkan analisis rasio tersebut, jika rata-rata industri untuk current ratio adalah dua kali, maka keadaan PT Indocement Tunggal Prakarsa Tbk pada rentang waktu 2014 hingga 2018 dalam kondisi baik mengingat rasionya di atas rata-rata industri. Kinerja terbaik perusahaan terjadi pada tahun 2014, hal tersebut ditunjukkan dengan rasio yang diperoleh lebih tinggi dibandingkan dengan keempat tahun lainnya.

Sedangkan penurunan tertinggi terjadi pada tahun 2017, yaitu sebesar 0,82 dibandingkan tahun sebelumnya (2016). Meskipun tiap tahun mengalami penurunan, perhitungan current ratio di tiap tahunnya tetap berada di atas rata-rata industri, sehingga secara rasio likuiditas untuk kinerja keuangan PT Indocement Tunggal Prakarsa Tbk dikatakan likuid atau dalam keadaan baik.

b. Rasio Cepat/Quick Ratio (QR)

Rasio Cepat $(\mathrm{QR})$ merupakan rasio yang digunakan untuk mengukur kemampuan perusahaan dalam membayar kewajiban jangka pendeknya dengan tidak memperhitungkan persediaan, karena persediaan memerlukan waktu yang relative lama untuk direalisir menjadi uang kas, walaupun kenyataannya 
mungkin persediaan bisa lebih likuid daripada piutang.

Tabel 6. Perhitungan Rasio Cepat/ Quick Ratio (QR) PT Indocement Tunggal Prakarsa Tbk. (dalam jutaan rupiah)

\begin{tabular}{|c|c|c|c|c|}
\hline Tahun & $\begin{array}{c}\text { Aktiva } \\
\text { Lancar }\end{array}$ & $\begin{array}{c}\text { Hutang } \\
\text { Lancar }\end{array}$ & Persediaan & $\begin{array}{c}\text { Quick } \\
\text { Ratio } \\
\text { (QR) }\end{array}$ \\
\hline 2014 & 16.086 .773 & 3.260 .559 & 1.665 .546 & 4,42 \\
\hline 2015 & 13.133 .854 & 2.687 .743 & 1.521 .197 & 4,32 \\
\hline 2016 & 14.424 .622 & 3.187 .742 & 1.780 .410 & 3,97 \\
\hline 2017 & 12.883 .074 & 3.479 .024 & 1.768 .603 & 3,19 \\
\hline 2018 & 12.315 .796 & 3.925 .649 & 1.837 .769 & 2,67 \\
\hline
\end{tabular}

Sumber: Data diolah peneliti 2020.

Tabel 6 mrnunjukan bahwa rasio cepat/quick ratio PT Indocement Tunggal Prakarsa Tbk mengalami penurunan setiap tahunnya. Pada tahun 2014, Quick Ratio sebesar 4,42 yang menunjukkan bahwa setiap Rp 1,00 utang dijamin oleh Rp 4,42 aktiva lancar di luar persediaan. Pada tahun 2015, rasio yang dihasilkan sebesar 4,32 yang menunjukkan bahwa setiap Rp 1,00 utang dijamin oleh $\mathrm{Rp}$ 4,32 aktiva lancar di luar persediaan. Meskipun mengalami penurunan sebesar 0,1 perusahaan masih bisa menutupi hutang lancarnya dengan aktiva lancarnya tanpa menjual persediaan.

Pada tahun 2016, rasio cepat yang dihasilkan sebesar 3,97 yang menunjukkan bahwa setiap Rp 1,00 utang dijamin oleh Rp 3,97 aktiva lancar di luar persediaan. Pada tahun 2017, rasio cepat yang dihasilkan sebesar 3,19 yang menunjukkan bahwa setiap Rp 1,00 utang dijamin oleh Rp 3,19 aktiva lancar di luar persediaan.

Pada tahun 2018, rasio cepat yang dihasilkan sebesar 2,67 yang menunjukkan bahwa setiap Rp 1,00 utang dijamin oleh Rp 2,67 aktiva lancar di luar persediaan.

Berdasarkan analisis rasio tersebut, jika rata-rata industri untuk quick ratio adalah 1,5 kali, maka keadaan PT Indocement Tunggal Prakarsa Tbk pada rentang waktu 2014 hingga 2018 dalam kondisi baik mengingat rasionya di atas rata-rata industri. Kinerja terbaik perusahaan terjadi pada tahun 2014, hal tersebut ditunjukkan dengan rasio yang diperoleh lebih tinggi dibandingkan dengan keempat tahun lainnya.

Sedangkan penurunan tertinggi terjadi pada tahun 2017, yaitu sebesar 0,78 dibandingkan tahun sebelumnya (2016).
Meskipun tiap tahun mengalami penurunan, perhitungan current ratio di tiap tahunnya tetap berada di atas rata-rata industri, sehingga secara rasio likuiditas untuk kinerja keuangan PT Indocement Tunggal Prakarsa Tbk dikatakan likuid atau dalam keadaan baik.

\section{Analisis Rasio Solvabilitas}

Rasio solvabilitas mengukur kemampuan perusahaan memenuhi kewajiban jangka panjangnya. Perusahaan yang tidak solvable adalah perusahaan yang total hutangnya lebih besar dibanding dengan total asetnya (Hanafi, 2013:41). Ada beberapa rasio solvabilitas. Di antara yang akan digunakan dalam penelitian ini adalah Rasio Hutang terhadap Total Aktiva/Debt to Asset Ratio (DAR) dan Rasio Hutang terhadap Ekuitas/Debt to Equity Ratio (DER).

a. Rasio Hutang terhadap Total Aktiva/Debt to Asset Ratio (DAR)

Rasio Hutang terhadap Total Aktiva/Debt to Asset Ratio (DAR) merupakan perbandingan antara hutang lancar dan hutang jangka panjang dan jumlah seluruh aktiva diketahui.

Tabel 7. Perhitungan Rasio Hutang terhadap Total Aktiva/Debt to Asset Ratio (DAR) PT Indocement Tunggal Prakarsa Tbk. (dalam jutaan rupiah)

\begin{tabular}{|c|c|c|c|}
\hline Tahun & Total Hutang & Total Aktiva & DAR \\
\hline 2014 & 4.100 .172 & 28.884 .973 & 0,14 \\
\hline 2015 & 3.772 .410 & 27.638 .360 & 0,14 \\
\hline 2016 & 4.011 .877 & 30.150 .580 & 0,13 \\
\hline 2017 & 4.307 .169 & 28.863 .676 & 0,15 \\
\hline 2018 & 4.566 .973 & 27.788 .562 & 0,16 \\
\hline
\end{tabular}

Sumber: Data diolah peneliti 2020.

Dari tabel 7 di atas, dapat diketahui Rasio Hutang terhadap Total Aktiva/Debt to Asset Ratio (DAR) tahun 2014 dan 2015 menunjukkan nilai yang sama, yakni sebesar 0,14 . Tingkat rasio ini menunjukkan $\mathrm{Rp} 0,14$ dari setiap $\mathrm{Rp}$ 1,00 merupakan pendanaan dari hutang. Dari sini dapat diketahui bahwa $14 \%$ dari aktiva perusahaan berasal dari hutang.

Pada tahun 2016, menunjukkan penurunan rasio sebesar 0,01 jika dibandingkan dengan tahun sebelumnya menjadi 0,13 . Hal ini menunjukkan bahwa $\mathrm{Rp}$ 0,13 dari setiap Rp 1,00 merupakan pendanaan dari hutang. Atau $13 \%$ dari aktiva perusahaan berasal dari hutang. 
Pada tahun 2017 terjadi kenaikan rasio sebesar 0,02 jika dibandingkan dengan tahun sebelumnya menjadi 0,15 . Hal ini menunjukkan bahwa $\mathrm{Rp} 0,15$ dari setiap $\mathrm{Rp}$ 1,00 merupakan pendanaan dari hutang. Atau $15 \%$ dari aktiva perusahaan berasal dari hutang. Hal ini disebabkan karena beban hutang yang meningkat, sedangkan asset yang terus menurun.

Pada tahun 2018, kembali menunjukkan kenaikan rasio sebesar 0,01 jika dibandingkan dengan tahun sebelumnya menjadi 0,16 . Hal ini menunjukkan bahwa $\mathrm{Rp} 0,16$ dari setiap $\mathrm{Rp}$ 1,00 merupakan pendanaan dari hutang. Atau $16 \%$ dari aktiva perusahaan berasal dari hutang.

Dari perhitungan rasio DAR menunjukkan bahwa kinerja keuangan PT Indocement Tunggal Prakarsa Tbk dalam keadaan baik. Meskipun dalam kurun waktu lima tahun terakhir mengalami peningkatan jumlah hutang, tetapi manajemen mampu menekan nilai rasio debt to asset ratio berada di bawah standar industri $35 \%$.

Berbeda halnya dalam penelitian Marianno pada tahun 2017, rata-rata rasio DAR PT Telekomunikasi Indonesia Tbk dari tahun 2011 hingga 2015 mencapai 40.47\%. Menurut Marriano, perusahaan masih dikatakan solvable karena nilai rasio berada di bawah $50 \%$. Namun apabila mengikuti standar industri $35 \%$, tentunya hal ini kurang baik bagi kinerja keuangan perusahaan karena berada di atas standar industri.

b. Rasio Hutang terhadap Ekuitas/Debt to Equity Ratio (DER)

Rasio Hutang terhadap Ekuitas/Debt to Equity Ratio (DER) merupakan perbandingan antara hutang-hutang dan ekuitas. Semakin tinggi rasio ini semakin besar hutang jangka panjang perusahaan dibanding dengan modal sendiri yang dimiliki perusahaan.

\section{Tabel 8. Perhitungan Rasio Hutang} terhadap Ekuitas/Debt to Equity Ratio (DER) PT Indocement Tunggal Prakarsa Tbk. (dalam jutaan rupiah)

\begin{tabular}{|c|c|c|c|}
\hline $\begin{array}{c}\text { Tahu } \\
\mathbf{n}\end{array}$ & Total Hutang & Ekuitas & DER \\
\hline 2014 & 4.100 .172 & 24.784 .801 & 0,16 \\
\hline 2015 & 3.772 .410 & 23.865 .950 & 0,16 \\
\hline 2016 & 4.011 .877 & 26.138 .703 & 0,15 \\
\hline 2017 & 4.307 .169 & 24.556 .507 & 0,17 \\
\hline 2018 & 4.566 .973 & 23.221 .589 & 0,20 \\
\hline
\end{tabular}

Sumber: Data diolah peneliti 2020.
Dari tabel 8 di atas, dapat diketahui Rasio Hutang terhadap Ekuitas/Debt to Equity Ratio (DER) tahun 2014 dan 2015 menunjukkan nilai yang sama, yakni sebesar 0,16 . Tingkat rasio ini menunjukkan $\mathrm{Rp} 0,16$ hutang perusahaan dijamin oleh Rp 1,00 modal perusahaan. Dari sini dapat diketahui bahwa $16 \%$ dari modal perusahaan berasal dari hutang.

Pada tahun 2016, nilai rasio turun 0,01 jika dibandingkan dengan tahun sebelumnya menjadi 0,15 . Tingkat rasio ini menunjukkan Rp 0,15 hutang perusahaan dijamin oleh $\mathrm{Rp}$ 1,00 modal perusahaan. Dari sini dapat diketahui bahwa $15 \%$ dari modal perusahaan berasal dari hutang.

Kenaikan nilai rasio justru terjadi pada tahun 2017 dan 2018, jika dibandingkan dengan tahun sebelumnya, tahun 2017 meningkat 0,02 menjadi 0,17 atau $17 \%$ dari modal perusahaan berasal dari utang dan 2018 meningkat 0,03 menjadi 0,20 atau $20 \%$ dari modal perusahaan berasal dari utang merupakan kenaikan tertinggi pada kurun waktu lima tahun terakhir.

Dari perhitungan rasio debt to equity ratio menunjukkan bahwa kinerja keuangan PT Indocement Tunggal Prakarsa Tbk dalam keadaan baik. Meskipun pada tiga tahun terakhir nilai rasio cenderung naik, namun jika dibandingkan dengan standar industri 0,8 atau $80 \%$, rasio perusahaan masih berada di bawah standar tersebut.

Berbeda halnya dalam penelitian Andres Maith pada tahun 2013, rasio debt to equity ratio PT Hanjaya Mandala Sampoerna Tbk dari tahun 2009 hingga 2012 menyentuh angka $100,9 \%$. Hal ini menunjukkan kinerja perusahaan PT Hanjaya Mandala Sampoerna Tbk sangatlah mengkhawatirkan, atau dapat dikatakan insolvable.

\section{Analisis Rasio Aktivitas}

Rasio aktivitas melihat seberapa besar efisiensi penggunaan asset oleh perusahaan. Rasio ini melihat seberapa besar dana tertanam pada asset perusahaan. Jika dana yang tertanam pada asset tertentu cukup besar, sementara dana tersebut mestinya bisa dipakai investasi pada asset lain yang lebih produktif, maka profitabilitas perusahaan tidak sebaik yang seharusnya. Ada beberapa rasio aktivitas, di 
antaranya dalam penelitian ini adalah sebagai berikut:

\section{a. Perputaran Piutang/Receivable Turn Over Ratio (RTR) \\ Rasio Perputaran Piutang/Receivable} Turnover Ratio (RTR) digunakan untuk mengukur berapa lama penagihan piutang selama satu periode. Dalam hal ini juga akan melihat rata-rata umur piutang. Rata-rata umur piutang melihat berapa lama waktu yang diperlukan untk melunasi piutang yang dipunyai perusahaan (mengubah piutang menjadi kas). Semakin lama rata-rata piutang, berarti semakin besar dana yang tertanam pada piutang. Menurut Kasmir (2008:187), Standar industri untuk rasio ini adalah sebanyak 15 kali dalam setahun.

Tabel 9. Perhitungan Perputaran Piutang/Receivable Turnover Ratio (RTR) PT Indocement Tunggal Prakarsa Tbk. (dalam jutaan rupiah)

\begin{tabular}{|c|c|c|c|c|}
\hline Tahun & Penjualan & $\begin{array}{c}\text { Piutang } \\
\text { Dagang }\end{array}$ & RTR & $\begin{array}{c}\text { Rata-rata umur } \\
\text { piutang }\end{array}$ \\
\hline 2014 & 19.9962 .64 & 2.670 .999 & 8 kali & 46 hari \\
\hline 2015 & 17.798 .055 & 2.534 .690 & 7 kali & 52 hari \\
\hline 2016 & 15.361 .894 & 2.605 .323 & 6 kali & 61 hari \\
\hline 2017 & 14.431 .211 & 2.503 .780 & 6 kali & 61 hari \\
\hline 2018 & 15.190 .283 & 2.992 .634 & 5 kali & 73 hari \\
\hline
\end{tabular}

Sumber: Data diolah peneliti 2020.

Dari tabel 9 di atas, perputaran piutang/receivable turnover ratio $\mathrm{PT}$ Indocement Tunggal Prakarsa Tbk berkisar antara 5 sampai 8 kali. Kemampuan perusahaan dalam hal perputaran dana yang tertanam dalam piutang sebanyak 8 kali pada tahun 2014, 7 kali pada tahun 2015, 6 kali pada tahun 2016, 6 kali pada tahun 2017 dan pada tahun 2017 menjadi 5 kali.

Pada periode lima tahun terakhir, perputaran piutang PT Indocement Tunggal Prakarsa Tbk cenderung turun setiap tahunnya. Penurunan terbesar terjadi pada tahun 2018 dengan rasio perputaran piutang yang hanya 5 kali dengan lama waktu rata-rata piutang adalah 73 hari. Meskipun penjualan perusahaan mengalami kenaikan pada tahun 2018, namun piutang dagang perusahaan juga mengalami kenaikan yang signifikan jika dibandingkan dengan tahun-tahun sebelumnya.

Jika dibandingkan dengan standar industri perputaran piutang sebanyak 15 kali, perputaran piutang PT Indocement Tunggal Prakarsa Tbk dapat dikatakan kurang baik karena berada di bawah standar industri. Rasio yang kecil menggambarkan bahwa modal kerja yang tertanam dalam piutang usaha semakin besar dan hal ini tidak baik bagi perusahaan karena lamanya penagihan piutang semakin panjang, atau dengan kata lain bahwa penagihan piutang tidak dapat tertagih pada waktu yang tepat.

b. Perputaran Persediaan/Inventory Turnover Ratio (ITR)

Rasio Perputaran Persediaan digunakan untuk mengukur berapa kali dana yang ditanam dalam persediaan berputar dalam satu periode. Semakin besar angka perputaran persediaan, semakin efektif perusahaan mengelola persediaannya. Sebaliknya, semakin kecil angka rata-rata umur persediaan, semakin buruk prestasi perusahaan, karena semakin besar dana yang tertanam pada asset persediaan tersebut. Menurut Kasmir (2008:187), Standar industri untuk rasio ini adalah sebanyak 20 kali dalam setahun.

Tabel 10.Perhitungan Perputaran Persediaan/Inventory Turnover Ratio (ITR) PT Indocement Tunggal Prakarsa Tbk. (dalam jutaan rupiah)

\begin{tabular}{|c|c|c|c|c|}
\hline Tahun & Penjualan & Persediaan & ITR & $\begin{array}{c}\text { Rata-rata } \\
\text { umur } \\
\text { persediaan }\end{array}$ \\
\hline 2014 & 19.9962 .64 & 1.665 .546 & 12 kali & 30 hari \\
\hline 2015 & 17.798 .055 & 1.521 .197 & 12 kali & 30 hari \\
\hline 2016 & 15.361 .894 & 1.780 .410 & 9 kali & 41 hari \\
\hline 2017 & 14.431 .211 & 1.768 .603 & 8 kali & 46 hari \\
\hline 2018 & 15.190 .283 & 1.837 .769 & 8 kali & 46 hari \\
\hline
\end{tabular}

Sumber: Data diolah peneliti 2020.

Berdasarkan perhitungan Rasio Perputaran Persediaan (ITR) PT Indocement Tunggal Prakarsa Tbk di atas, pada tahun 2014 perusahaan melakukan perputaran persediaan sebanyak 12 kali dengan siklus persediaan selama 30 hari. Dan pada tahun 2015, perusahaan melakukan perputaran sebanyak 12 kali dalam siklus 30 hari. Pada tahun 2016, perusahaan melakukan perputaran 9 kali dalam siklus 41 hari. Pada tahun 2017 dan 2018 perusahaan melakukan perputaran sebanyak 8 kali dalam siklus yang sama 46 hari.

PT Indocement Tunggal Prakarsa Tbk menunjukkan kurang efektifnya perusahaan dalam hal pengelolaan persediaan perusahaannya. Karena perputaran persediaan 
menunjukkan angka yang sangat kecil dan cenderung menurun setiap tahunnya. Begitu juga jika dilihat dari rata-rata umur persediaan yang menunjukkan angka antara 30 hingga 46 menunjukkan bahwa prestasi perusahaan tidak terlalu baik, karena asset terlalu lama tertanam pada persediaan.

c. Perputaran Modal Kerja/Working Capital Turnover Ratio (WCTR)

Rasio Perputaran Modal Kerja digunakan untuk mengukur atau menilai keefektifan modal kerja perusahaan. Modal kerja selalu dalam keadaan beroperasi atau berputar dalam perusahaan. Periode perputaran modal kerja dimulai saat kas yang diinvestasikan dalam komponen modal kerja sampai kembali menjadi kas. Semakin besar nilai rasio yang dihasilkan, maka semakin bagus kinerja perusahaan, atau dapat dikatakan perusahaan semakin efektif dalam memanfaatkan working capital.

Tabel 11. Perhitungan Rasio Perputaran Modal Kerja/Working Capital Turnover Ratio (WCTR) PT Indocement Tunggal Prakarsa Tbk. (dalam jutaan rupiah)

\begin{tabular}{c|c|c|c}
\hline Tahun & Penjualan & Modal Kerja rata-rata & WCTR \\
\hline 2014 & 19.9962 .64 & 12.826 .214 & $1,56 \mathrm{kali}$ \\
\hline 2015 & 17.798 .055 & 10.446 .111 & $1,70 \mathrm{kali}$ \\
\hline 2016 & 15.361 .894 & 11.236 .880 & $1,37 \mathrm{kali}$ \\
\hline 2017 & 14.431 .211 & 9.404 .050 & $1,53 \mathrm{kali}$ \\
\hline 2018 & 15.190 .283 & 8.390 .147 & $1,81 \mathrm{kali}$ \\
\hline
\end{tabular}

Sumber: Data diolah peneliti 2020.

Dilihat pada tabel 11, tahun 2014 nilai perputaran modal kerja PT Indocement Tunggal Prakarsa Tbk sebesar 1,56 kali, yang artinya setiap $\mathrm{Rp} 1,00$ modal kerja dapat menghasilkan Rp 1,56 penjualan. Pada tahun 2015 nilai perputaran modal kerja mengalami sedikit kenaikan menjadi 1,70 kali yang berarti setiap $\mathrm{Rp}$ 1,00 modal kerja dapat menghasilkan Rp 1,70 penjualan. Pada tahun 2016, nilai perputaran modal kerja kembali mengalami penurunan menjadi 1,37 kali yang berarti setiap Rp 1,00 modal kerja dapat menghasilkan Rp 1,37 penjualan.

Pada tahun 2017, nilai perputaran modal kerja kembali mengalami kenaikan menjadi 1,53 kali yang berarti setiap Rp 1,00 modal kerja dapat menghasilkan $\mathrm{Rp} 1,53$ penjualan. Kenaikan terbesar terjadi pada tahun 2018 yaitu nilai perputaran modal kerja menjadi 1,81 kali yang berarti setiap Rp 1,00 modal kerja dapat menghasilkan Rp 1,81 penjualan.

\section{d. Perputaran Aktiva Tetap/Fixed Assets Turnover Ratio (FATR)}

Rasio Perputaran Aktiva Tetap digunakan untuk mengukur berapa kali dana yang ditanamkan dalam aktiva tetap berputar dalam satu periode. Semakin tinggi angka perputaran aktiva tetap, semakin efektif perusahaan mengelola asetnya. Rasio ini menunjukkan sejauh mana kemampuan perusahaan menghasilkan penjualan berdasarkan aktiva tetap yang dimiliki perusahaan. Menurut Kasmir (2008:187), Standar industri untuk rasio ini adalah sebanyak 5 kali dalam setahun.

Tabel 13. Perhitungan Rasio Perputaran Aktiva Tetap/Fixed Assets Turnover Ratio (FATR) PT Indocement Tunggal Prakarsa Tbk. (dalam jutaan rupiah)

\begin{tabular}{|c|c|c|c|}
\hline Tahun & Penjualan & Total Aktiva Tetap & FATR \\
\hline 2014 & 19.9962 .64 & 12.143 .632 & $1,64 \mathrm{kali}$ \\
\hline 2015 & 17.798 .055 & 13.813 .892 & $1,29 \mathrm{kali}$ \\
\hline 2016 & 15.361 .894 & 14.643 .695 & $1,05 \mathrm{kali}$ \\
\hline 2017 & 14.431 .211 & 14.979 .453 & $0,96 \mathrm{kali}$ \\
\hline 2018 & 15.190 .283 & 14.637 .185 & $1,04 \mathrm{kali}$ \\
\hline
\end{tabular}

Sumber: Data diolah peneliti 2020.

Nilai perputaran aktiva tetap/fixed assets turnover ratio (FATR) PT Indocement Tunggal Prakarsa Tbk dilihat dari tabel 12 mengalami peningkatan dan penurunan. Pada tahun 2014 menunjukkan nilai 1,64 yang berarti setiap $R p$ 1,00 yang diinvestasikan pada aktiva tetap, dapat menghasilkan pendapatan sebesar $\mathrm{Rp}$ 1,64 dari total aktiva tetap. Pada tahun 2015 mengalami penurunan nilai rasio perputaran aktiva tetap menjadi 1,29 yang berarti setiap Rp 1,00 yang diinvestasikan pada aktiva tetap, dapat menghasilkan pendapatan sebesar Rp 1,29 dari total aktiva tetap.

Pada tahun 2016, kembali turun menjadi 1,05 yang artinya setiap $\mathrm{Rp} 1,00$ yang diinvestasikan pada aktiva tetap, dapat menghasilkan pendapatan sebesar Rp 1,05 dari total aktiva tetap. Pada tahun 2017, turun menjadi 0,96 yang artinya setiap Rp 1,00 yang diinvestasikan pada aktiva tetap, dapat menghasilkan pendapatan sebesar Rp 0,96 dari total aktiva tetap. Pada tahun 2018, nilai perputaran aktiva tetap naik menjadi 1,04 yang artinya setiap Rp 1,00 yang diinvestasikan pada 
aktiva tetap, dapat menghasilkan pendapatan sebesar Rp 1,04 dari total aktiva tetap.

Dalam periode lima tahun terakhir, rasio perputaran aktiva tetap PT Indocement Tunggal Prakarsa Tbk berada pada nilai 0,96 kali hingga 1,64 kali. Nilai tersebut jika dibandingkan dengan standar industri masih berada di bawah standar, yang berarti perusahaan belum mampu memaksimalkan kapasitas aktiva tetap yang dimiliki jika dibandingkan dengan perusahan lain.

\section{e. Rasio Perputaran Aktiva/Total Assets Turnover Ratio (TATR)}

Rasio Perputaran Aktiva digunakan untuk mengukur perputaran semua aktiva yang dimiliki perusahaan. Rasio ini mengukur berapa kali total aktiva perusahaan menghasilkan volume penjualan. Menurut Kasmir (2008:187), standar industri untuk rasio ini adalah sebanyak 2 kali dalam setahun.

Tabel 13. Perhitungan Rasio Perputaran Aktiva/Total Assets Turnover Ratio (FATR) PT Indocement Tunggal Prakarsa Tbk. (dalam jutaan rupiah)

\begin{tabular}{c|c|c|c|}
\hline Tahun & Penjualan & Total Aktiva & TATR \\
\hline 2014 & 19.9962 .64 & 28.884 .973 & $0,69 \mathrm{kali}$ \\
\hline 2015 & 17.798 .055 & 27.638 .360 & $0,64 \mathrm{kali}$ \\
\hline 2016 & 15.361 .894 & 30.150 .580 & $0,51 \mathrm{kali}$ \\
\hline 2017 & 14.431 .211 & 28.863 .676 & $0,50 \mathrm{kali}$ \\
\hline 2018 & 15.190 .283 & 27.788 .562 & $0,55 \mathrm{kali}$ \\
\hline
\end{tabular}

Sumber: Data diolah peneliti 2020.

Dari perhitungan rasio perputaran aktiva di atas menunjukkan penurunan mulai tahun 2014 hingga 2017 berturut-turut sebesar 0,69, $0,64,0,51,0,50$, dan 0,55. Hal ini disebabkan PT Indocement Tunggal Prakarsa belum mampu secara optimal dalam mengelola seluruh aktivanya. Hal ini nampak dari rasio perputaran aktiva sangat lambat, bahkan nilainya berada di bawah angka 1 . Pada tahun 2018, mulai terjadi kenaikan dibandingkan tahun sebelumnya meskipun belum signifikan menjadi 0,55 kali. Hal ini berarti perusahaan sedikit mampu mengelola aktiva perusahaan lebih baik.

Kondisi perusahaan jika dilihat dari rasio perputaran aktiva dapat dikatakan kurang baik, karena masih berada di bawah standar industri 2 kali. Perusahaan harus lebih mengoptimalkan dalam mengelola seluruh aktiva dalam perusahaan sehingga nilai perputaran aktivanya akan jauh lebih baik.

\section{Analisi Rasio Profitabilitas}

Rasio profitabilitas mengukur kemampuan perusahaan dalam menghasilkan keuntungan (profit) pada tingkat penjualan, asset, modal dan modal saham tertentu. Ada beberapa rasio yang akan dibahas dalam penelitian ini, di antaranya adalah Net Profit Margin (NPM), Return On Investment (ROI), dan Return On Equity (ROE).

a. Net Profit Margin (NPM)

Net Profit Margin merupakan rasio yang digunakan untuk mengukur margin laba bersih setelah pajak. Rasio ini menghitung sejauh mana kemampuan perusahaan menghasilkan laba bersih pada tingkat penjualan tertentu (Hanafi, dalam Fithriyah, 2018:95). Rasio ini juga dapat diinterpretasikan sebagai kemampuan perusahaan menekan biaya-biaya (ukuran efisien) di perusahaan pada periode tertentu.

Net Profit Margin yang tinggi menunjukkan kemampuan perusahaan menghasilkan laba yang tinggi pada tingkat penjualan tertentu. Secara umum, rasio yang rendah menunjukkan ketidakefisienan manajemen dalam mengoperasikan perusahaan, begitu pula sebaliknya. Menurut Kasmir (2008:208), standar industri untuk rasio ini adalah sebanyak $20 \%$.

Tabel 14. Perhitungan Net Profit Margin (NPM) PT Indocement Tunggal Prakarsa Tbk. (dalam jutaan rupiah)

\begin{tabular}{c|c|c|c|}
\hline Tahun & EAT (Laba Bersih) & Penjualan & NPM \\
\hline 2014 & 5.153 .776 & 19.9962 .64 & $25,8 \%$ \\
\hline 2015 & 4.258 .600 & 17.798 .055 & $23,9 \%$ \\
\hline 2016 & 3.800 .464 & 15.361 .894 & $24,7 \%$ \\
\hline 2017 & 1.837 .668 & 14.431 .211 & $12,7 \%$ \\
\hline 2018 & 1.241 .944 & 15.190 .283 & $8,2 \%$ \\
\hline \multicolumn{3}{|c|}{ Rata-rata Net Profit Margin } & $\mathbf{1 9 , 0 6 \%}$ \\
\hline
\end{tabular}

Sumber: Data diolah peneliti 2020.

Berdasarkan perhitungan Net Profit Margin PT Indocement Tunggal Prakarsa Tbk di atas, dapat dilihat bahwa terjadi fluktuasi di setiap tahunnya. Pada tahun 2014 diperoleh nilai 25,8\%, kemudian pada tahun 2015 mengalami penurunan menjadi $23,9 \%$. Pada tahun 2016, meski penjualan dan laba bersih perusahaan tidak sebesar tahun sebelumnya, kinerja Net Profit Margin-nya lebih baik dibandingkan tahun sebelumnya yaitu 24,7\% .

Hal yang berbanding terbalik justru terjadi pada tahun 2017 dimana nilai rasionya 
turun tajam menjadi $12,7 \%$. Penurunan ini dapat dilihat dari penjualan yang terus menurun dan laba bersih yang turun lebih dari separuh laba bersih tahun sebelumnya. Dan penurunan ini berlanjut pada tahun 2018 dengan nilai NPM menjadi $8,2 \%$ dan merupakan nilai rasio terendah dalam lima tahun terakhir.

Dari tabel 14 di atas menunjukkan $\mathrm{Net}$ Profit Margin PT Indocement Tunggal Prakarsa Tbk pada tahun 2014 hingga 2016 adalah efektif karena jika dibandingkan dengan standar industri $20 \%$ berada di atas standar tersebut. Namun, perusahaan mengalami penurunan yang signifikan pada tahun 2017 menjadi hanya $12,7 \%$ dan berlanjut pada tahun 2018 menjadi hanya 8,2\%. Jika dibandingkan dengan standar industri 20\%, kondisi ini menempatkan perusahaan tidak efektif dalam melakukan penjualan dan mendapatkan laba bersih.

Kinerja Net Profit Margin yang awalnya efektif menjadi tidak efektif karena penurunan yang signifikan pada tahun 2017, sehingga ratarata Net Profit Margin PT Indocement Tunggal Prakarsa Tbk selama lima tahun terakhir hanya $19,06 \%$ sehingga secara rasio profitabilitas untuk kinerja keuangan PT Indocement Tunggal Prakarsa Tbk kurang baik karena nilai rasio yang terus turun mengindikasikan bahwa manajemen belum dapat mengambil keputusan yang efektif sehingga laba bersih perusahaan semakin turun. Manajemen harus lebih efisien sehingga pendapatan dapat dimaksimalkan lebih baik dan dapat mengurangi beban biaya seminimal mungkin untuk mendapatkan laba bersih yang lebih baik. Berikut pertumbuhan Net Profit Margin PT Indocement Tunggal

\section{b. Return On Investment (ROI)}

Rasio ini mengukur tingkat penghasilan bersih yang diperoleh dari total aktiva perusahaan. Return On Investment biasanya digunakan untuk mengetahui kemampuan perusahaan secara keseluruhan di dalam menghasilkan keuntungan dengan jumlah keseluruhan aktiva yang tersedia di dalam perusahaan. Menurut Kasmir (2008:208), Standar industri untuk rasio ini adalah sebanyak $30 \%$.
Tabel 15. Perhitungan Return On Investment (ROI) PT Indocement Tunggal Prakarsa Tbk. (dalam jutaan rupiah)

\begin{tabular}{|c|c|c|c|}
\hline Tahun & $\begin{array}{c}\text { EAT (Laba } \\
\text { Bersih) }\end{array}$ & Total Aktiva & ROI \\
\hline 2014 & 5.153 .776 & 28.884 .973 & $17,8 \%$ \\
\hline 2015 & 4.258 .600 & 27.638 .360 & $15,4 \%$ \\
\hline 2016 & 3.800 .464 & 30.150 .580 & $12,6 \%$ \\
\hline 2017 & 1.837 .668 & 28.863 .676 & $6,4 \%$ \\
\hline 2018 & 1.241 .944 & 27.788 .562 & $4,5 \%$ \\
\hline \multicolumn{3}{|c|}{ Rata-rata Return On Investment } & $\mathbf{1 1 , 3 4 \%}$ \\
\hline
\end{tabular}

Sumber: Data diolah peneliti 2020.

Dilihat dari tabel 15, pertumbuhan ROI PT Indocement Tunggal Prakarsa Tbk pada periode 2014 hingga 2018 terus mengalami penurunan. Pada tahun 2014, ROI perusahaan berada di angka $17,8 \%$, kemudian turun menjadi $15,4 \%$ pada tahun 2018. Hal yang sama terjadi pada tahun 2016 yang kembali turun menjadi $12,6 \%$. Penurunan paling signifikan terjadi pada tahun 2017 yaitu 6,4\% atau turun hampir separuh dari nilai tahun sebelumnya. Hingga pada tahun 2018 menjadi hanya $4,5 \%$ dan menjadi yang terendah dalam kurun waktu lima tahun terakhir. Sehingga apabila dikalkulasikan selama kurun waktu lima tahun tersebut, rata-rata nilai return on investment perusahaan hanya berada di angka $11,34 \%$.

Meskipun dalam kurun waktu lima tahun terakhir perusahaan tidak mengalami kerugian, akan tetapi total aktiva yang ada tidak terlalu berpengaruh terhadap penjualan yang dilakukan oleh perusahaan. Sehingga kinerja perusahaan dilihat dari pertumbuhan Return On Investment apabila mengikuti standar industri yang ada, menunjukkan bahwa PT Indocement Tunggal Prakarsa Tbk tidak efektif karena masih berada dibawah standar industri $30 \%$.

c. Return On Equity (ROE)

Rasio ini mengukur kemampuan perusahaan dalam menghasilkan laba bersih berdasarkan modal tertentu. Rasio ini merupakan ukuran profitabilitas dilihat dari sudut pandang pemegang saham. Menurut Harahap (dalam Fithriyah, 2018:105), return on equity digunakan untuk mengukur besarnya pengembalian terhadap pemegang saham. Angka tersebut menunjukkan seberapa efektif manajemen memanfaatkan investasi para pemegang saham. Menurut Kasmir (2008:208), Standar industri untuk rasio ini adalah sebanyak $40 \%$. 
Tabel 16. Perhitungan Return On Equity (ROE) PT Indocement Tunggal Prakarsa Tbk. (dalam jutaan rupiah)

\begin{tabular}{c|c|c|c|}
\hline Tahun & $\begin{array}{c}\text { EAT (Laba } \\
\text { Bersih) }\end{array}$ & Ekuitas & ROE \\
\hline 2014 & 5.153 .776 & 24.784 .801 & $20,8 \%$ \\
\hline 2015 & 4.258 .600 & 23.865 .950 & $17,8 \%$ \\
\hline 2016 & 3.800 .464 & 26.138 .703 & $14,5 \%$ \\
\hline 2017 & 1.837 .668 & 24.556 .507 & $7,5 \%$ \\
\hline 2018 & 1.241 .944 & 23.221 .589 & $5,3 \%$ \\
\hline \multicolumn{3}{|c|}{ Rata-rata Return On Equity } & $\mathbf{1 3 , 2} \%$ \\
\hline
\end{tabular}

Sumber: Data diolah peneliti 2020.

Dari perhitungan Return On Equity di atas, menunjukkan bahwa PT Indocement Tunggal Prakarsa Tbk mengalami penurunan di tiap tahunnya. Pada tahun 2014, nilai $R O E$ perusahaan berada di angka 20,8\% dan merupakan yang tertinggi pada kurun waktu lima tahun terakhir. Kemudian pada tahun 2015, nilai $R O E$ perusahan turun menjadi $17,8 \%$ dan terus menurun hingga pada tahun 2016 menjadi $14,5 \%$.

Pada tahun 2017, terjadi penurunan yang cukup signifikan yaitu hampir separuh dari angka tahun sebelumnya menjadi hanya $7,5 \%$. Hingga akhirnya pada tahun 2018, nilai $R O E$ perusahaan menjadi $5,3 \%$ atau yang paling rendah dalam kurun waktu lima tahun terakhir.

Penurunan nilai Return On Equity pada kurun waktu tersebut disebabkan karena adanya penurunan asset dan penurunan terhadap laba setelah bunga dan pajak. Namun berbeda dengan tahun 2016, meskipun secara nilai rasio mengalami penurunan tetapi terdapat peningkatan nilai ekuitas pada perusahaan.

Nilai Return On Equity perusahaan setiap tahunnya berada dibawah standar industri $40 \%$. Bahkan apabila diambil rata-rata selama lima tahun terakhir, nilai Return On Equity perusahaan hanya berada di angka 13,2\%. Hal ini mengindikasikan secara rasio profitabilitas, untuk kinerja keuangan PT Indocement Tunggal Prakarsa Tbk dapat dikatakan tidak efektif atau tidak memenuhi target. Berikut adalah gambaran pertumbuhan Return On Equity PT Indocement Tunggal Prakarsa Tbk pada tahun 2014 hingga 2018.

\section{KESIMPULAN}

Berdasarkan hasil penelitian yang dilakukan oleh peneliti mengenai analisis rasio keuangan untuk menilai kinerja keuangan PT Indocement Tunggal Prakarsa Tbk periode tahun 2014-2018. Dalam tugas akhir ini ada empat jenis perhitungan rasio yang digunakan untuk menilai posisi dan kinerja keuangan perusahaan yaitu rasio likuiditas, rasio solvabilitas, rasio aktivitas, dan rasio profitabilitas. Adapun kesimpulan dari penelitian ini yaitu:

1. Berdasarkan analisis dan interpretasinya serta penilaian kinerja keuangan PT Indocement Tunggal Prakarsa Tbk yang telah dibahas di dalam bab sebelumnya, maka dapat di ambil kesimpulan bahwa dari hasil analisis rasio likuiditas, kinerja keuangan perusahaan PT Tbk selama periode 2014-2018 menurut perhitungan rasio lancar/current ratio sudah berada di atas standar industri yang artinya perusahaan mampu mengelola aktiva lancarnya sehingga rasio lancarnya tidak terlalu besar. Jika dilihat dari rasio cepat/quick ratio, kinerja keuangan perusahaan PT Indocement Tunggal Prakarsa Tbk juga berada di atas standar industri yang berarti perusahaan mampu menutupi hutang lancarnya tanpa menjual persediaan.

2. Dari hasil analisis solvabilitas, kinerja keuangan perusahaan PT Indocement Tunggal Prakarsa Tbk periode 2014-2018 dilihat dari rasio hutang terhadap total aktiva/debt to assets ratio dalam membayar hutang jangka panjang dengan mengguakan aktiva yang dimiliki dalam keadaan baik karena berada di bawah standar industri, namun setiap tahunnya, prosentase tingkat hutang mengalami kenaikan, karena semakin besar jumlah modal pinjaman yang digunakan dengan menghasilkan keuntungan dibanding dengan aktiva yang dimiliki. Jika dilihat dari rasio hutang terhadap ekuitas/debt to equity ratio, kinerja perusahaan dalam membayar hutang jangka panjangnya dengan menggunakan modal yang dimiliki dala, keadaan yang baik juga, artinya perusahaan mampu untuk mengendalikan hutang mereka sehingga prosentase hutang perusahaan berada di bawah standar industri.

3. Dari hasil analisis aktivitas, kinerja keuangan perusahaan PT Indocement 
Tunggal Prakarsa Tbk periode 2014-2018 jika dilihat dari rasio perputaran piutang/receivable turnover ratio adalah tidak baik, karena perputaran piutang dalam kurun waktu lima tahun terakhir sangatlah rendah. Jika dilihat dari rasio perputaran persediaan/inventory turnover ratio, kinerja keuangan perusahaan menunjukkan ketidakefektifannya dalam hal pelolaan persediaannya, hal ini dibuktikan dengan rendahnya nilai perputaran persediaan perusahaan selama kurun waktu lima tahun terakhir. Jika dilihat dari perputaran modal kerja/working capital turnover ratio, kinerja keuangan masih tidak stabil. Jika dilihat dari rasio perputaran aktiva tetap/fixed assets turnover ratio juga menunjukkan angka yang kecil dalam perputaran aktiva tetapnya. Dan jika dilihat dari perputaran total aktiva/total assets turnover ratio, kinerja keuangan kurang optimal dalam mengelola seluruh aktivanya.

4. Dari hasil analisis profitabilitas, kinerja keuangan perusahaan PT Indocement Tunggal Prakarsa Tbk periode 2014-2018 jika dilihat dari rasio net profit margin (NPM), perusahaan cenderung mengalami penurunan dalam kurun waktu lima tahun terakhir dan hal ini menunjukkan bahwa penjualan dan laba yang terus menurun. Jika dilihat dari nilai return on investment, di akhir periode bisa diketahui meskipun tidak mengalami kerugian, tetapi peningkatan total aktiva tidak sejalan dengan peningkatan laba bersih. Dan jika dilihat dari nilai return on equity, menunjukkan laba bersih yang dimiliki perusahaan untuk menutupi pengeluaran investasi bernilai besar namun tetap berada di bawah standar industri yang ada sehingga perusahaan dikatakan tidak baik atau tidak efisien. Hal ini disebabkan karena kurang mengoptimalkan modal sendiri untuk menghasilkan laba bersih.

\section{SARAN}

Berdasarkan kesimpulan yang telah dipaparkan di atas, maka penulis dapat memberikan beberapa saran baik untuk perusahaan maupun untuk penelitian yang selanjutnya.

1. Bagi pihak manajemen perusahaan PT Indocement Tunggal Prakarsa Tbk.

Perusahaan diharapkan bisa memperbaiki rasio likuiditasnya, karena likuiditas atau modal kerja merupakan rasio yang paling penting bagi perusahaan. Efisiensi penggunaan modal kerja akan mempengaruhi rasio-rasio yang lainnya, terutama rasio profitabilitasnya. Sehingga perusahaan mampu memenuhi kewajiban jangka pendek dan jangka panjangnya untuk menyeimbangkan antara rasio-rasio lainnya, yaitu dilakukan dengan menekankan beban bunga dengan menutup hutang jangka pendek maupun hutang jangka panjang yang jatuh tempo.

Perusahaan juga dapat melakukan promosi dan inovasi terhadap produknya, sehingga dapat meningkatkan pendapatan perusahaan. Serta melakukan inovasi dalam pemasaran seperti membuka agen-agen di setiap kecamatan agar segmentasi pasar dari produk perusahaan semakin luas, dan meningkatkan permintaan konsumen atas produk yang dihasilkan oleh perusahaan.

2. Bagi Investor

Jika dilihat dari rasio likuiditas current ratio dan quick ratio, investor bisa menanamkan sahamnya pada PT Indocement Tunggal Prakarsa Tbk karena perusahaan tersebut likuid dan memilik prospek jangka panjang yang baik.

3. Bagi penelitian selanjutnya

4. Selain memaparkan analisis, penelitian selanjutnya diharapkan memaparkan analisis dengan dibandingkan dengan standar industri dan kebijakan yang seharusnya diambil oleh perusahaan, serta kebijakan yang diambil oleh investor secara detail.

\section{DAFTAR PUSTAKA}

Erica, Denny. 2017. Analisa Laporan Keuangan Untuk Menilai Kinerja Perusahaan PT Semen Indonesia Tbk (Persero). Perspektif. XV(2): 89-94. Diunduh melalui 
http://www.ejournal.bsi.ac.id. $(15 / 12 / 2019)$

Fithriyah, Ainul. 2018. Analisis Laporan Keuangan Sebagai Penilaian Kinerja Keuangan Perusahaan (Studi Kasus pada PT Telekomunikasi Indonesia Tbk Periode 2013-2017). Skripsi. Fakultas Ekonomi Universitas Islam Negeri (UIN) Maulana Malik Ibrahim Malang. Diunduh melalui : http://etheses.uin-malang.ac.id. (14/12/2019)

Gunawan, Agung. 2012. Analisis Rasio Keuangan Untuk Menilai Kinerja Keuangan Pt Fajar Surya Wisesa, Tbk. Periode Tahun 2009, 2010 dan 2011. Tugas Akhir. Fakultas Ekonomi Universitas Negeri Yogyakarta. Diunduh melalui : https://eprints.uny.ac.id. (13/12/2019)

Harahap, Masnuripa. 2018. Analisis Rasio Likuiditas Sebagai Alat Penilaian Untuk Mengukur Kinerja Keuangan Pada PT Prodia Widyahusada Tbk. Skripsi. Fakultas Ekonomi dan Bisnis Islam Universitas Islam Negeri Sumatera Utara Medan. Diunduh melalui : http://repository.uinsu.ac.id. $(13 / 12 / 2019)$

Indocement Tunggal Prakarsa Tbk. 2018. Volume Penjualan Semen. Diunduh melalui

http://www.indocement.co.id.

$(11 / 12 / 2019)$

2018. Laporan Tahunan 2018. Diunduh melalui http://www.indocement.co.id. $(11 / 12 / 2019)$

2017. Laporan Tahunan 2017. Diunduh melalui : http://www.indocement.co.id. $(11 / 12 / 2019)$

2016. Laporan Tahunan 2016. Diunduh melalui http://www.indocement.co.id. $(11 / 12 / 2019)$

2015. Laporan Tahunan 2015. Diunduh melalui http://www.indocement.co.id. $(11 / 12 / 2019)$
. 2014. Laporan Tahunan 2014. Diunduh melalui http://www.indocement.co.id. $(11 / 12 / 2019)$

Kasmir. 2008. Analisis Laporan Keuangan. Cetakan ke-9. Jakarta: PT Grafindo Persada.

Kementerian Keuangan Republik Indonesia. 2017. Informasi APBN 2018. Diunduh melalui : http://www.kemenkeu.go.id $(10 / 12 / 2019)$

Maith, Hendry A. 2013. Analisa Laporan Keuangan dalam Mengukur Kinerja Keuangan Pada PT Hanjaya Mandala Sampoerna Tbk. Jurnal EMBA. 1(3): 619-628. Diunduh melalui : https://ejournal.unsrat.ac.id. $(14 / 12 / 2019)$

Marginingsih, R. 2017. Penilaian Kinerja Perusahaan dengan Menggunakan Analisa Rasio Keuangan pada Perusahaan Telekomunikasi di Indonesia. Cakrawala. VII(1): 14-21. Diunduh melalui http://www.ejournal.bsi.ac.id. $(15 / 12 / 2019)$

Nurudin, Moh. 2018. Analisis Rasio Likuiditas Dan Rasio Profitabilitas Terhadap Kinerja Keuangan (Studi Pada PT. Indofood Sukses Makmur, Tbk Tahun 2014-2016). Skripsi. Fakultas Ekonomi Universitas Mercu Buana Yogyakarta. Diunduh melalui : http://eprints.mercubuanayogya.ac.id. (14/12/2019)

Oktavia, Anggun. 2015. Analisis Sumber Dan Penggunaan Modal Kerja Pada PT Global Multipack Palembang. Laporan Akhir. Politeknik Negeri Sriwijaya. Diunduh melalui : http://eprints.polsri.ac.id. $(14 / 12 / 2019)$

Republika. 2018. Penjualan Industri Semen Tumbuh 95 Persen. Diunduh melalui:http://m.republika.co.id/berita /ekonomi/makro/18/02/05/p3o78j368 -penjualan-industri-semen-tumbuh95-persen. (14/12/2019)

Ridha, Muhammad. 2017. Analisis Rasio Keuangan Dalam Menilai Kinerja 
Keuangan BUMN (Studi Kasus PT. Perkebunan Nusantara III Medan). Skripsi. Fakultas Ekonomi dan Bisnis Islam Universitas Islam Negeri Sumatera Utara Medan. Diunduh melalui : http://repository.uinsu.ac.id. $(13 / 12 / 2019)$

Sugiyono. 2018. Metode Penelitian Kuantitatif, Kualitatif, dan $R \& D$. Cetakan ke-28. Bandung: CV Alfabeta.

Suhendro, Dedi. 2017. Analisis Profitabilitas dan Likuiditas Untuk Menilai Kinerja Keuangan pada PT Siantar Top Tbk. Human Falah. 4(2): 218-235. Diunduh melalui http://jurnal.uinsu.ac.id. (14/12/2019)

Sujarweni, VW. 2017. Analisis Laporan Keuangan (Teori, Aplikasi, dan Hasil Penelitian). Yogyakarta: Pustaka Baru Press.

William, Marianno. 2017. Analisis Rasio Keuangan untuk Menilai Kinerja Keuangan Perusahaan (Studi Kasus di PT Telekomunikasi Indonesia Tbk). Skripsi. Fakultas Ekonomi Universitas Sanata Dharma Yogyakarta. Diunduh melalui : https://repository.usd.ac.id. $(13 / 12 / 2019)$

Yani, Rika. 2016. Analisis Laporan Keuangan Untuk Menilai Kinerja Keuangan Perusahaan (Studi Pada PT. Asiaplast Industries Tbk, Periode 2009 - 2014). Skripsi. Fakultas Ekonomi Dan Ilmu Sosial Universitas Islam Negri Sultan Sarif Kasim Riau Pekanbaru. Diunduh melalui : http://repository.uinsuska.ac.id. (16/12/2019) 